\title{
Threshold Cointegration, Asymmetric Causality and Wagner's Law: The African Experience Revisited
}

\author{
Yaya Keho ${ }^{1}$ \\ ${ }^{1}$ Ecole Nationale Supérieure de Statistique et d'Economie Appliquée (ENSEA) Abidjan, Côte d'Ivoire \\ Correspondence: Yaya Keho, Ecole Nationale Supérieure de Statistique et d'Economie Appliquée (ENSEA) \\ Abidjan, 08 BP 03 Abidjan 08, Côte d'Ivoire. Tel: 225-2244-4124. E-mail: yayakeho@ yahoo.fr
}

Received: November 9, 2016

Accepted: January 7, 2017

Online Published: April 302017

doi:10.5539/ijef.v9n5p171

URL: https://doi.org/10.5539/ijef.v9n5p171

\begin{abstract}
This study re-examines the Wagner's law of public expenditure for six sub-Saharan African countries while relaxing the assumption of a symmetric adjustment process underlying standard cointegration tests and error-correction models. The empirical methodology uses threshold cointegration tests to establish that there is a long-run relationship between government expenditure and per capita GDP for five countries, with income being positively related to public spending. Furthermore, the results of asymmetric Granger-causality tests provide support for Wagner's law in the long run for five countries (Cameroon, Cote d'Ivoire, Ghana, Kenya, and Senegal), while the Keynesian view holds only in the short run for three countries (Benin, Cameroon, and Cote d'Ivoire). The short run evidence for two countries (Kenya and Senegal) support both Wagner's law and Keynesian view.
\end{abstract}

Keywords: Wagner's law, threshold cointegration, asymmetric error-correction model, causality

\section{Introduction}

The relationship between government expenditure and economic growth is a subject of debate in theoretical and empirical economic literature. Theoretically, two conventional views describe this relationship. First, the Wagner's law stresses that as a country develops, the share of public spending tends to rise to meet the increased protective, administrative and social functions of the state (Wagner, 1958). This view suggests a unidirectional causality running from per capita income to government expenditure. On the other hand, the Keynesian view argues that increases in public spending stimulate economic growth, especially in times of recession (Keynes, 1936). This line of though suggests that causality is running from public expenditure to per capita income.

An extensive empirical research has examined the validity of these two competing views. The empirical methodology made use of either the Engle-Granger method or the multivariate approach of Johansen and Juselius (1990). Recently, there is a growing body of empirical studies using the bounds test developed by Pesaran et al. (2001). The empirical evidence from this literature is however mixed and controversial across countries, data, model specifications and econometric techniques. While some studies (Ram, 1987; Ahsan et al., 1996; Cotsomitis et al., 1996; Thornton, 1999; Islam, 2001; Al-Faris, 2002; Chang, 2002; Aregbeyen, 2006; Narayan et al., 2008; Srinivasan, 2013; Bayrak and Esen, 2014) found support for Wagner's Law, other studies (Ansari et al., 1997; Biswal et al., 1999; Ghali, 1999; Burney, 2002; Huang, 2006) reported results contradicting Wagner's law. Some other studies (Singh \& Sahni, 1984; Ahsan et al., 1992; Afxentiou \& Serletis, 1996; Sinha, 1998; Bagdigen \& Cetintas, 2004; Dogan \& Tang, 2006) showed no evidence for both propositions. Richter and Paparas (2013) used Greek data from 1833 to 2010 and provided evidence in favor of Wagner's law. On the contrary, Ogbonna (2015) reexamined the case of Greece using data for the period 1948-2010 and failed to find evidence supporting either Wagner's law or Keynesian hypothesis. Hassan et al. (2008) used the ARDL bounds test to provide strong support for Wagner's law in Turkey over the period 1950-2005. Bayrakdar et al. (2015) also confirmed the validity of Wagner's for Turkey over the period 1998-2014. Narayan et al. (2008) used cointegration and Granger causality tests and found mixed evidence in support of Wagner's law for Chinese provinces. Magazzino (2012) also found evidence in favor of Wagner's law in the case of Italy for the period 1960-2008. Narayan et al. (2012) found evidence of Wagner's law for 15 Indian states using panel techniques. Samadi and Abolhasan Belgi (2013) used recent developments in econometrics to examine the validity of Wagner law for a panel of Organization of Islamic Conference member states. Controlling for cross-sectional dependence, their 
estimation results confirm the Wagner's law in all countries. Magazzino et al. (2015) investigated the case of 27 European Union member countries for the period 1980-2013 using panel methods that account for cross-section dependence. Their results supported Wagner's law in eight countries, and Keynesian view in four countries. For 12 countries, there is no causal relationship public expenditure and GDP. Atasoy and Gür (2016) applied the ARDL model and the Kalman filter and found that Wagner's law holds for China during the period 1982-2011.

Studies on African countries have yielded mixed and conflicting results. Ansari et al. (1997) found that there is no long run relationship between government expenditure and national income in Ghana, Kenya and South Africa. In the short-run, only Ghana shows evidence supporting Wagner's law. Olomola (2004), Aregbeyen (2006), Ogbonna (2012) and Akinlo (2013) for Nigeria, Menya and Wolde-Rufael (2012) for South Africa, Mutuku and Kimani (2012) for Kenya, and Salih (2012) for Sudan found evidence supporting Wagner's law. On the contrary, the studies by Omoke (2009), Chimobi (2009), Sevitenyi (2012), and Muse et al. (2013) for Nigeria, Ebaidalla (2013) for Sudan, and Gadinabokao and Daw (2013) for South Africa provided support for the Keynesian view. Ayo et al. (2011) found supportive evidence for both hypotheses both in the short run and the long run in Nigeria. Besides, Frimpong and Oteng-Abayie (2009) supported neither Wagner's law nor Keynesian view for three West African Monetary Zone countries (Gambia, Ghana and Nigeria). Kamasa and Ofori-Abebrese (2015) applied the VAR approach and found results supporting Wagner's law in Ghana over the period 1980-2010. Keho (2015) applied a frequency domain analysis to ten African countries. He found evidence supporting Wagner's law in Cameroon, Ghana and Nigeria. The Keynesian view holds for Gabon, Senegal and South Africa. Odhiambo (2015) employed the ARDL approach to examine the case of South Africa. He found that both government expenditure and economic growth cause each other in the short run while in the long run Wagner's law holds. More recently, Keho (2016) reexamined the validity of Wagner's law in six African countries over the period 1960-2013. He applied a cointegration techniques that control for structural breaks. He found supporting evidence of Wagner's law in Ghana over the period 1960-2013 and in Cote d'Ivoire for the period 1960-1995. For Kenya, the evidence supports both Wagner's law and Keynesian view for the period 1960-1991. For Benin, Senegal and South Africa, the results do not support Wagner's law or Keynesian theory. Thabane and Lebina (2016) applied the ARDL bounds testing procedure to examine the economic growth and government expenditure nexus in Lesotho for the period 1980 to 2012. Their results are consistent with Wagner's law and fail to support the Keynesian view. Udo et al. (2016) examined the case of sixteen West African economies for the period 1970-2012. Their results support Wagner's law for Guinea and Cape Verde, while Keynesian view holds for Togo, Mauritania, Liberia and Sierra Leone. However, there is bidirectional causality between economic growth and government expenditure in Nigeria, Mali, Ghana, Gambia, and Cote d'Ivoire. For Benin, Guinea Bissau, Senegal, Burkina Faso and Niger, there is no relationship between the two variables. Paul and Furahisha (2017) used cointegration technique and found strong support for both Wagner's law and Keynesian view in the case of Tanzania for the period 1978-2014.

A major limitation of most empirical works using cointegration tests is that they implicitly assume the adjustment process of the variables to be strictly symmetric. This assumption indicates that, regardless of a positive or negative equilibrium error, the adjustment speed remains identical. The state of the economy and whether or not economy is growing or decreasing does not matter. If government expenditure behaves differently when income is decreasing than when it is increasing, then standard cointegration techniques may not be accurate in characterizing the true relationship between government spending and economic growth. Balke and Fomby (1997) and Enders and Granger (1998) showed that the power of standard cointegration tests fall under an asymmetric adjustment process.

While empirical tests of Wagner's law have been extensive, no recent studies have considered asymmetry in testing this hypothesis for African countries. The main contribution of this paper is to reexamine the relationship between government expenditure and income by using nonlinear cointegration and asymmetric modeling. In particular, we employ the threshold autoregression approach developed by Enders and Granger (1998) and Enders and Siklos (2001). These methods are suitable for testing whether public spending behaves asymmetrically over the business cycle. It is widely acknowledged that there is a very close connection between the budget and the business cycle through automatic fiscal stabilizers. To the extent that business is asymmetric, the change in public spending may also be asymmetric. Recent studies suggested the possibility that fiscal policy may have nonlinear growth effects, in the sense that both the size and the sign of the response of real variables to fiscal policy could be different depending on the initial conditions in which such policy is implemented (e.g. Bertola \& Drazen, 1993; Giavazzi et al. 2000; Perotti, 1999).

The remainder of the study is organized as follows. Section 2 presents the econometric methodology of the study. Section 3 analyses the empirical results. Finally, Section 4 provides summary and gives some policy implications. 


\section{Econometric Methodology}

The empirical analysis proceeds in three steps. First, we begin by testing for unit roots to ascertain the order of integration of the variables. Second, we test for possible cointegration between the variables. The third step determines the direction of causation among the variables. Wagner's law requires unidirectional causality running from income to public spending.

\subsection{Unit Root Test}

Standard unit root tests such as augmented Dickey-Fuller and Phillips and Perron (1988) are widely used to ascertain the order of integration of variables. However, these tests exhibit lower power in detecting non-linearity. Therefore, this study employs a newly developed test proposed by Kapetanios et al. (2003) (henceforth, KSS) to determine whether government expenditure and income are non-linear stationary. The KSS test is based on testing the presence of non-stationarity against non-linear but globally stationary exponential smooth transition autoregressive (ESTAR) process:

$$
\Delta z_{t}=\gamma z_{t-1}\left(1-\exp \left(-\theta z_{t-1}^{2}\right)\right)+\sum_{i=1}^{p} \phi_{i} \Delta z_{t-i}+v_{t}
$$

where $z_{t}$ is the variable considered, $v_{t}$ an i.i.d. error with zero mean and constant variance, and $\theta \geq 0$ is the transition parameter. We are interested in testing the null hypothesis of $\theta=0$ against the alternative of $\theta>0$. Under the null hypothesis, $z_{t}$ follows a linear unit root process, whereas it is a non-linear stationary ESTAR process under the alternative. Because the parameter $\gamma$ is not identified under the null, it is not feasible to directly test the null hypothesis. Kapetanios et al. (2003) proposed a first-order Taylor series approximation to $1-\exp \left(-\theta z_{t-1}^{2}\right)$ under the null of $\theta=0$ and replaced Eq.(1) by the following regression:

$$
\Delta z_{t}=\xi+\delta z_{t-1}^{3}+\sum_{i=1}^{p} \phi_{i} \Delta z_{t-i}+v_{t}
$$

The null hypothesis to be tested is then expressed as $\delta=0$ (non-stationarity) against the alternative $\delta<0$ (non-linear ESTAR stationarity). The estimated critical values for different values of $p$ are tabulated in Kapetanios et al. (2003).

\subsection{Threshold Cointegration}

If the variables are I(1), we proceed with long-run relationship and cointegration tests. We employ the threshold cointegration approach proposed by Enders and Granger (1998) and Enders and Siklos (2001). This approach is a residual-based two-stage estimation procedure. Following Engle and Granger (1998), the cointegration relation is estimated as follows:

$$
g_{t}=\beta_{0}+\beta_{1} y_{t}+e_{t}
$$

where $g$ is the natural logarithm of real per capita government expenditure and $y$ is the natural logarithm of real per capita GDP. The residual term $e$ is expected to be stationary.

The second stage tests for the stationarity of the residual term $e$ using unit root tests. Pippenger and Goering (1993), Balke and Fomby (1997), Enders and Granger (1998) and Enders and Siklos (2001) showed that standard tests for unit-root and cointegration all exhibit low power in the presence of asymmetric adjustment towards the long-run relationship. If government spending behaves differently when income is decreasing than when it is increasing, then standard cointegration tests are no longer reliable. Enders and Granger (1998) and Enders and Siklos (2001) replace the standard ADF auxiliary regression with the following Threshold Autoregressive (TAR) process:

$$
\Delta e_{t}=I_{t} \rho_{1} e_{t-1}+\left(1-I_{t}\right) \rho_{2} e_{t-1}+\sum_{i=1}^{p} \phi_{i} \Delta e_{t-i}+\varepsilon_{t}
$$

where $I_{t}$ is the heaviside indicator function such that $I_{t}=1$ if $e_{t-1} \geq \tau$ and $I_{t}=0$ if $e_{t-1}<\tau ; \tau$ is the value of the

threshold. It is also possible to allow the adjustment to depend on the previous change in $e_{t-1}$ rather than on the previous level $e_{t-1}$. In this case, the heaviside indicator becomes $I_{t}=1$ if $\Delta e_{t-1} \geq \tau$ and $I_{t}=0$ if $\Delta e_{t-1}<\tau$.

Once Equation (4) is estimated, the null hypothesis $\rho_{1}=\rho_{2}=0$ of no cointegration is tested through the F-statistic. However, the distribution of this statistics is not standard. The appropriate critical values are tabulated by Enders and Siklos (2001). The rejection of $\rho_{1}=\rho_{2}=0$ implies the existence of a cointegration relationship between the variables. This enables us to proceed with a further test for symmetric adjustment $\left(\rho_{l}=\rho_{2}\right)$ by using a standard F-test. Rejecting both the null hypotheses of $\rho_{1}=\rho_{2}=0$ and $\rho_{1}=\rho_{2}$ implies the existence of threshold 
cointegration with asymmetric adjustment.

In most cases, the value of the threshold is unknown, and it has to be estimated along with $\rho_{1}$ and $\rho_{2}$. To obtain a consistent estimate of the threshold, we follow a grid search procedure. Typically, the residual series is sorted into an increasing order. The central $80 \%$ of observations are then considered as potential thresholds. For each of these potential thresholds, Equation (4) is estimated by OLS and the consistent estimated threshold is found by selecting the value that minimises the sum of squared residuals.

\subsection{Short-Run Dynamics and Granger-Causality}

Under the assumption of threshold cointegration, the short-run dynamics of the series is examined with an asymmetric error correction model. In most studies applying threshold cointegration, only the speed of the adjustment to the long-run relationship changes with regimes, while the autoregressive coefficients remain constant. In this study, we relax this assumption, allowing the speed of the adjustment as well as the short-run dynamics to vary across regimes. Thus, our asymmetric error correction model is specified as follows:

$$
\begin{aligned}
\Delta g_{t} & =A_{11}^{+}(L) \Delta g_{t-1}^{+}+A_{11}^{-}(L) \Delta g_{t-1}^{-}+A_{12}^{+}(L) \Delta y_{t-1}^{+}+A_{12}^{-}(L) \Delta y_{t-1}^{-}+\alpha_{1}^{+} e_{t-1}^{+}+\alpha_{1}^{-} e_{t-1}^{-}+\mu_{1 t} \\
\Delta y_{t} & =A_{21}^{+}(L) \Delta g_{t-1}^{+}+A_{21}^{-}(L) \Delta g_{t-1}^{-}+A_{22}^{+}(L) \Delta y_{t-1}^{+}+A_{22}^{-}(L) \Delta y_{t-1}^{-}+\alpha_{2}^{+} e_{t-1}^{+}+\alpha_{2}^{-} e_{t-1}^{-}+\mu_{2 t}
\end{aligned}
$$

where $e_{t-1}^{+}=I_{t} e_{t-1}, e_{t-1}^{-}=\left(1-I_{t}\right) e_{t-1}, A_{i j}(L)$ are pth order lag polynomials in the lag operator $\mathrm{L}, \Delta g_{t}^{+}=\max \left(\Delta g_{t}, 0\right)$, $\Delta g_{t}^{-}=\min \left(\Delta g_{t}, 0\right) ; \Delta y_{t}^{+}$and $\Delta y_{t}^{-}$are similarly defined. The choice of the appropriate lag length is based on the AIC.

The estimated coefficients on $e_{t-1}^{+}$and $e_{t-1}^{-}$determine the rate at which positive and negative deviations adjust to long-run relationship. The null $\alpha^{+}=\alpha^{-}$indicates symmetry in the long-run adjustment, and can be tested by using a standard F-test. On the other hand, short-run symmetry $A_{i j}^{+}(L)=A_{i j}^{-}(L)$ can also be tested using a standard F-test. In the absence of short-run asymmetry, we estimate the following threshold error-correction model:

$$
\begin{aligned}
& \Delta g_{t}=A_{11}(L) \Delta g_{t-1}+A_{12}(L) \Delta y_{t-1}+\alpha_{1}^{+} e_{t-1}^{+}+\alpha_{1}^{-} e_{t-1}^{-}+\mu_{1 t} \\
& \Delta y_{t}=A_{21}(L) \Delta g_{t-1}+A_{22}(L) \Delta y_{t-1}+\alpha_{2}^{+} e_{t-1}^{+}+\alpha_{2}^{-} e_{t-1}^{-}+\mu_{2 t}
\end{aligned}
$$

The short-run Granger causality tests are performed by testing whether all the coefficients of $\Delta y_{t-i}$ or $\Delta g_{t-i}$ are jointly statistically different from zero based on standard F-tests, while long-run causality Granger causality analysis tests whether the $\alpha_{i}$ coefficients of the error-correction are significant.

\section{Data and Empirical Results}

This study uses annual data on real per capita government expenditures (G) and real per capita GDP for a sample of six African countries: Benin, Cameroon, Cote d'Ivoire, Ghana, Kenya and Senegal. The GDP deflator was used to express data in constant 2005 US dollars. Meanwhile, the effect of population growth was removed by using per capita values. Data cover the period from 1965 to 2013 and were obtained from the World Development Indicators, available online. Data were also transformed into natural logarithms.

Table 1 reports some descriptive statistics on the variables. The standard deviations of variables indicate significant fluctuations in per capita income and public spending over the time period under study. Also evident from the Table is the positive association between the two variables. However, correlation does not mean

\begin{tabular}{|c|c|c|c|c|c|c|c|c|c|c|c|}
\hline \multirow[b]{2}{*}{ Country } & \multicolumn{5}{|c|}{ GDP } & \multicolumn{5}{|c|}{ Gouvernement expenditure } & \multirow[t]{2}{*}{ Corr. } \\
\hline & Mean & Med. & Std. & Min & $\operatorname{Max}$ & Mean & Med. & Std. & Min & Max & \\
\hline Benin & 478.4 & 464.3 & 47.3 & 411.8 & 582.8 & 67.4 & 66.7 & 7.65 & 49.5 & 87.1 & -0.13 \\
\hline Cameroon & 912.3 & 907.8 & 177.2 & 640.7 & 1356.1 & 84.7 & 84.8 & 18.4 & 54.1 & 120.1 & 0.68 \\
\hline Cote d'Ivoire & 1231.5 & 1131.4 & 246.6 & 940.1 & 1836.6 & 159.9 & 156.8 & 74.8 & 70.8 & 327.3 & 0.89 \\
\hline Ghana & 456.9 & 440.3 & 95.5 & 320.8 & 769.3 & 55.8 & 52.1 & 24.0 & 18.8 & 153.3 & 0.90 \\
\hline Kenya & 503.6 & 511.2 & 65.2 & 322.9 & 632.4 & 79.3 & 76.2 & 20.5 & 32.5 & 109.2 & 0.79 \\
\hline Senegal & 739.1 & 729.5 & 54.6 & 635.1 & 837.4 & 120.0 & 119.0 & 20.1 & 94.7 & 166.2 & 0.47 \\
\hline
\end{tabular}
causality. Our goal in this study is to find out whether this positive association implies that higher government spending induces higher income or higher income leads to higher public spending.

Table 1. Descriptive statistics of variables 
As a first step of our empirical analysis, we test for the order of integration of the series by means of the well-known Phillips and Perron (PP) (1988) and Kwiatkowsk et al. (1992) tests. These tests have been performed under the models with constant and trend for the level series and with constant for series in first difference. The results of these tests are reported in Table 2. They show that all the variables are non-stationary in their level but become stationary after taking the first difference, except government spending ( $\mathrm{g}$ ) for Benin. Table 3 presents the results of the non-linear ESTAR stationary test of Kapetanios et al. (2003), which provide similar evidence that the series are all integrated of order one or I (1), except the public spending variable for Benin.

Table 2. Results of conventional linear unit root tests

\begin{tabular}{|c|c|c|c|c|c|c|c|c|}
\hline & \multicolumn{4}{|c|}{ PP } & \multicolumn{4}{|c|}{ KPSS } \\
\hline & $\mathrm{g}$ & $\mathrm{y}$ & $\Delta \mathrm{g}$ & $\Delta \mathrm{y}$ & $\mathrm{g}$ & $\mathrm{y}$ & $\Delta \mathrm{g}$ & $\Delta \mathrm{y}$ \\
\hline Benin & -3.655 & -2.410 & -12.400 & -8.066 & 0.132 & 0.170 & 0.274 & 0.339 \\
\hline Cameroon & -2.040 & -1.619 & -6.791 & -5.170 & 0.131 & 0.141 & 0.093 & 0.114 \\
\hline Cote d'Ivoire & -2.556 & -2.643 & -5.822 & -4.499 & 0.156 & 0.106 & 0.268 & 0.202 \\
\hline Ghana & -0.979 & -0.231 & -5.483 & -4.596 & 0.207 & 0.228 & 0.329 & 0.393 \\
\hline Kenya & -2.823 & -2.968 & -4.808 & -6.130 & 0.130 & 0.158 & 0.288 & 0.299 \\
\hline Senegal & -1.834 & -1.451 & -5.317 & -9.459 & 0.096 & 0.211 & 0.158 & 0.367 \\
\hline
\end{tabular}

Note. $\mathrm{g}$ and $\mathrm{y}$ are the symbols for log of real per capita government expenditure and real per capita GDP, respectively.

Table 3. Results of the KSS nonlinear unit root test

\begin{tabular}{|c|c|c|c|c|}
\hline \multirow[b]{2}{*}{ Country } & \multicolumn{2}{|c|}{ Level } & \multicolumn{2}{|c|}{ First difference } \\
\hline & $\mathrm{g}$ & $\mathrm{y}$ & $\Delta \mathrm{g}$ & $\Delta \mathrm{y}$ \\
\hline Benin & -4.811 & -2.698 & -5.867 & -6.202 \\
\hline Cameroon & -2.229 & -0.937 & -4.594 & -4.585 \\
\hline Cote d'Ivoire & -2.202 & -2.847 & -3.930 & -4.328 \\
\hline Ghana & -1.511 & 0.201 & -3.689 & -3.185 \\
\hline Kenya & -2.910 & -1.141 & -4.070 & -3.251 \\
\hline Senegal & -2.019 & -1.825 & -4.515 & -6.076 \\
\hline
\end{tabular}

Note. $\mathrm{g}$ and $\mathrm{y}$ are the symbols for log of real per capita government expenditure and real per capita GDP, respectively. Critical values at the $5 \%$ level are -3.40 in level and -2.22 in first difference, and are taken from Kapetanios et al. (2003).

Given the unit root tests results, we further test for threshold cointegration between the two variables. We estimate the long-run relationships and use the residuals to test for threshold cointegration. We exclude Benin from the cointegration analysis. For this country, government expenditure is mean-reverting in the long-run regardless of real income. For the rest of the countries, the results of the threshold tests are reported in Table 4. The empirical evidence in this Table shows that the null of no cointegration $\left(\rho_{1}=\rho_{2}=0\right)$ can be rejected for all countries, suggesting the existence of stationary long-run relationships between government spending and per capita income. In addition, the F-statistics reject the null hypothesis of symmetric adjustment $\left(\rho_{1}=\rho_{2}\right)$ in favor of asymmetric threshold adjustment toward the long run relationship. Note that the point estimates of $\rho_{1}$ and $\rho_{2}$ suggest substantially faster convergence for negative (below threshold) deviations from long run equilibrium than positive (above threshold) deviations, except for Cameroon and Ghana. For example, for Cote d'Ivoire, negative deviations from the long run relationship resulting from decreases in government spending or increases in income are eliminated at a rate of 91 percent per year, while positive deviations are eliminated at only 6.5 percent per year. Similarly, for Kenya, negative deviations from the long run relationship stemming from decreases in government spending or increases in income are eliminated much faster than positive deviations. In that sense, decreases in government spending and increases in real per capita GDP are reversed quickly whereas increases in government spending and decreases in real per capita GDP linger for a while for Cote d'Ivoire, Kenya and Senegal. On the other hand, for Cameroon and Ghana positive deviations from the long run relationship stemming from increases in government spending or decreases in real per capita income are eliminated relatively quickly. 
Table 4. Results of threshold cointegration tests

\begin{tabular}{lcccccccc}
\hline Country & Flag & AIC & $\rho 1$ & $\rho 2$ & $\Phi(\rho 1=\rho 2=0)$ & $\rho 1=\rho 2$ & $\tau$ & $\beta 1$ \\
\hline Cameroon & TAR & -2.60 & $-0.615(-3.91)$ & $-0.187(-1.08)$ & $8.21^{*}$ & $3.345^{* *}$ & 0.083 & $0.614(9.19)$ \\
Cote d'Ivoire & MTAR & -1.73 & $-0.065(-0.67)$ & $-0.909(-5.65)$ & $16.49^{*}$ & $19.088^{*}$ & -0.069 & $1.959(12.41)$ \\
Ghana & MTAR & -1.23 & $-0.974(-3.37)$ & $-0.448(-3.41)$ & $10.16^{*}$ & $3.048^{* *}$ & 0.173 & $1.937(13.84)$ \\
Kenya & TAR & -2.75 & $-0.168(-1.56)$ & $-0.463(-3.81)$ & $8.20^{*}$ & $3.506^{* *}$ & -0.070 & $1.202(6.23)$ \\
Senegal & MTAR & -3.90 & $-0.560(-2.85)$ & $-1.130(-5.49)$ & $15.11^{*}$ & $8.742^{*}$ & -0.033 & $0.863(6.52)$ \\
\hline
\end{tabular}

Note. Numbers in parentheses are t-statistics. * (**) indicates significance at 5\% (10\%) level. Critical values are based on Enders and Siklos (2001).

Having established cointegration between the variables as well as asymmetric adjustment in the long-run relationships, it is possible to estimate the asymmetric version of the standard error correction model. For Benin, where government expenditure is stationary, we estimate a dynamic model of the form:

$$
\begin{aligned}
g_{t} & =A_{11}(L) g_{t-1}+A_{12}^{+}(L) \Delta y_{t-1}^{+}+A_{12}^{-}(L) \Delta y_{t-1}^{-}+\alpha_{1}^{+} e_{t-1}^{+}+\alpha_{1}^{-} e_{t-1}^{-}+\mu_{1 t} \\
\Delta y_{t} & =A_{21}(L) g_{t-1}+A_{22}^{+}(L) \Delta y_{t-1}^{+}+A_{22}^{-}(L) \Delta y_{t-1}^{-}+\alpha_{2}^{+} e_{t-1}^{+}+\alpha_{2}^{-} e_{t-1}^{-}+\mu_{2 t}
\end{aligned}
$$

The results of the Granger-causality tests are presented in Table 5. The point estimates of the error correction terms for GDP are not significant for all countries. This indicates that real per capita GDP is weakly exogenous to the public spending. The results also suggest a long run unidirectional causal relationship running from per capita GDP to government expenditure in Cameroon, Cote d'Ivoire, Ghana, Kenya and Senegal. These findings favor Wagner's law.

With respect to the short-run causality, the F-statistics suggest that public expenditures cause per capita GDP in Benin, Cameroon and Cote d'Ivoire. There is evidence of short-run bidirectional causality between public expenditures and per capita GDP for Kenya and Senegal. Conversely, no short-run causal relationship exists between the two variables in Ghana. This finding suggests that the movements of government spending and per capita income do not have significant impacts upon each other in the short-run.

\begin{tabular}{|c|c|c|c|c|c|c|c|c|}
\hline & Eq. & $\alpha+a$ & $\alpha-\mathrm{a}$ & $\mathrm{F} 11 \mathrm{~b}$ & $\mathrm{~F} 12 \mathrm{c}$ & $(\alpha+=\alpha-=0)$ & Symmetry $(\alpha+=\alpha-)$ & $\mathrm{p}$ \\
\hline \multirow[t]{4}{*}{ Benin } & $\Delta \mathrm{g}$ & - & - & 11.48 & 0.49 & - & - & 2 \\
\hline & & & & $(0.001)$ & $(0.611)$ & & & \\
\hline & $\Delta \mathrm{y}$ & - & - & 0.90 & 8.84 & - & - & 2 \\
\hline & & & & $(0.413)$ & $(0.000)$ & & & \\
\hline \multirow[t]{4}{*}{ Cameroon } & $\Delta \mathrm{g}$ & -0.868 & 0.037 & 1.66 & 0.99 & 8.38 & 9.59 & 4 \\
\hline & & $(-3.68)$ & $(0.12)$ & $(0.181)$ & $(0.426)$ & $(0.001)$ & $(0.004)$ & \\
\hline & $\Delta \mathrm{y}$ & -0.039 & 0.227 & 4.19 & 3.33 & 0.70 & 1.33 & 4 \\
\hline & & $(-0.21)$ & $(0.98)$ & $(0.007)$ & $(0.021)$ & $(0.501)$ & $(0.255)$ & \\
\hline \multirow[t]{4}{*}{ Cote d'Ivoire } & $\Delta \mathrm{g}$ & -0.004 & -0.429 & 3.45 & 0.29 & 2.89 & 4.27 & 1 \\
\hline & & $(-0.03)$ & $(-2.40)$ & $(0.070)$ & $(0.590)$ & $(0.066)$ & $(0.044)$ & \\
\hline & $\Delta y$ & 0.041 & 0.021 & 11.92 & 4.15 & 0.51 & 0.07 & 1 \\
\hline & & $(0.98)$ & $(0.33)$ & $(0.001)$ & $(0.047)$ & $(0.601)$ & $(0.792)$ & \\
\hline \multirow[t]{4}{*}{ Ghana } & $\Delta \mathrm{g}$ & -0.843 & -0.426 & 2.77 & 1.02 & 5.23 & 4.14 & 1 \\
\hline & & $(-2.27)$ & $(-2.53)$ & $(0.103)$ & $(0.316)$ & (0.009) & $(0.048)$ & \\
\hline & $\Delta \mathrm{y}$ & 0.077 & 0.023 & 5.95 & 0.20 & 0.36 & 0.24 & 1 \\
\hline & & $(0.74)$ & $(0.49)$ & $(0.019)$ & $(0.649)$ & $(0.695)$ & $(0.623)$ & \\
\hline \multirow[t]{4}{*}{ Kenya } & $\Delta \mathrm{g}$ & -0.036 & -0.444 & 2.38 & 3.13 & 3.99 & 3.28 & 3 \\
\hline & & $(-0.29)$ & $(-2.71)$ & $(0.080)$ & $(0.015)$ & $(0.028)$ & $(0.078)$ & \\
\hline & $\Delta y$ & -0.033 & -0.003 & 1.76 & 3.03 & 0.06 & 0.03 & 3 \\
\hline & & $(-0.34)$ & $(-0.03)$ & $(0.138)$ & $(0.042)$ & $(0.938)$ & $(0.860)$ & \\
\hline \multirow[t]{4}{*}{ Senegal } & $\Delta \mathrm{g}$ & -0.024 & -0.634 & 8.08 & 4.83 & 7.98 & 10.55 & 3 \\
\hline & & $(-0.16)$ & $(-3.94)$ & $(0.000)$ & $(0.006)$ & $(0.001)$ & $(0.002)$ & \\
\hline & $\Delta y$ & -0.055 & -0.328 & 3.89 & 2.61 & 1.99 & 3.12 & 3 \\
\hline & & $(-0.35)$ & $(-1.90)$ & $(0.017)$ & $(0.034)$ & $(0.151)$ & $(0.086)$ & \\
\hline
\end{tabular}

Table 5. Tests of exogeneity, Granger-causality and symmetry in error correction models

Note. (a) The entries are estimated error correction terms given the threshold adjustment with t-statistics in parentheses.

(b) The entries are estimated F-statistics that the variable does not Granger cause itself with the p-values in parentheses.

(c) The entries are estimated F-statistics that the variable does not Granger cause the other variable with p-values in parentheses. 
In light of these findings, we can conclude that government expenditures in Benin, Cameroon and Cote d'Ivoire follow the Keynesian view in the short-run while Kenya and Senegal exhibit evidence supporting both Wagner's law and Keynesian view. Wagner's law holds in the long-run in Cameroon, Cote d'Ivoire, Ghana, Kenya and Senegal. Thus, the Keynesian view holds only in the short-run and not in the long-run. These findings suggest that restrictions on public spending limit the ability of the countries to use fiscal policy to stabilize their economies during recessions. Also, the growth in government spending is influenced by per capita economic growth. This link operates through tax revenues, since how much the government can increase its expenditures is determined by its revenues. Governments mobilize more tax revenues from growing economic activity to make up their spending. Our findings for Ghana and Kenya contradict with those provided by Ansari et al. (1997) and Frimpong and Oteng-Abayie (2009). Ansari et al. (1997) found that in Ghana and Kenya there is no long run relationship between government expenditure and national income and that Wagner's law is supported only in the short-run for Ghana. The findings of Frimpong and Oteng-Abayie (2009) do support neither Wagner's hypothesis nor Keynesian view for these two countries.

\section{Conclusion}

Wagner's law of increasing government size has been the topic of a burgeoning empirical literature in the past few decades. A number of studies have used the Granger causality test to examine the causal relationship between government expenditure and national income. The evidence from these studies is inconclusive and controversial across countries and methodologies.

This study re-examined the validity of Wagner's law and its reverse for six sub-Saharan African countries over the period 1965 to 2013. It relaxed the implicit assumption of a symmetric adjustment process underlying conventional cointegration tests and allows the possibility of asymmetry in the relationship between public expenditure and economic growth. The empirical methodology used threshold cointegration and asymmetric Granger-causality tests. We found that there is a long-run cointegration relationship between government expenditure and per capita GDP for five countries, with per capita GDP positively related to public spending. In addition, the results of Granger-causality tests provide support for Wagner's law in the long-run for five countries (Cameroon, Cote d'Ivoire, Ghana, Kenya, and Senegal) whereas the Keynesian paradigm is confirmed only in the short-run for three countries (Benin, Cameroon, and Cote d'Ivoire). The short-run government expenditure movements in Kenya and Senegal are consistent with both Wagner's law and Keynesian doctrine.

The findings suggest that government spending can be used as a policy instrument to stimulate economic growth in the short-run. Therefore, restrictions on public spending limit the ability of the countries to use fiscal policy to stabilize their economies during recessions. This is particularly relevant for member countries of monetary unions, namely Benin, Cameroon, Cote d'Ivoire and Senegal.

The results presented in this paper provided the first evidence of asymmetric relationship between government expenditure and national income for a sample of sub-Saharan African countries. It has added to our understanding of the government spending-economic growth nexus and calls for the need to revise traditional linear specifications on Granger-causality.

\section{References}

Afxentiou, P. C., \& Serletis, A. (1996). Government Expenditures in the European Union: Do They Converge or Follow Wagner's Law? International Economic Journal, 10(3), 33-47. http://dx.doi.org/10.1080/10168739600080018

Ahsan, S. M., Andy, C. K., \& Balbir, S. S. (1992). Public Expenditure and National Income Causality: Further Evidence on the Role of Omitted Variables. Southern Economic Journal, 58(3), 623-634. http://dx.doi.org/10.2307/1059830

Ahsan, S., Kwan A., \& Sahni, B. (1996). Cointegration and Wagner's hypothesis: Time series evidence for Canada. Applied Economics, 28(8), 1055-1058. http://dx.doi.org/10.1080/000368496328182

Akinlo, A. E. (2013). Government Spending and National Income Nexus for Nigeria. Global Journal of Business Research, 7(1), 33-41.

Al-Faris, A. F. (2002). Public expenditure and economic growth in the Gulf Cooperation Council Countries. Applied Economics, 34(9), 1187-1193. http://dx.doi.org/ 10.1080/00036840110090206

Ansari, M. I., Gordon, D. V., \& Akuamoach, C. (1997). Keynes versus Wagner: Public Expenditure and National Income for Three African Countries. Applied Economics, 29(4), 543-550. http://dx.doi.org/10.1080/000368497327038 
Aregbeyen, O. (2006). Cointegration, Causality and Wagner's Law: A Test for Nigeria, 1970-2003. Central Bank of Nigeria Economic and Financial Review, 44(2), 1-17.

Atasoy, B. S., \& Gür, T. H. (2016). Does the Wagner's Hypothesis Hold for China? Evidence from Static and Dynamic Analyses. Panoeconomicus, 63(1), 45-60. http://dx.doi.org/10.2298/PAN1601045A

Ayo, O. S., Ifeakachukwu, N. P., \& Ditimi, A. (2011). A Trivariate Causality Test among Economic Growth, Government Expenditure and Inflation Rate: Evidence from Nigeria. The Journal of World Economic Review, 6(2), 189-199.

Bagdigen, M., \& Cetintas, H. (2004). Causality between Public Expenditure and Economic Growth: The Turkish Case. Journal of Economic and Social Research, 6(1), 53-72.

Balke, N. S., \& Fomby, T. B. (1997). Threshold Cointegration. International Economic Review, 38(3), 627-645. http://dx.doi.org/10.2307/2527284

Bayrak, M., \& Esen, Ö. (2014). Examining the validity of Wagner's law in the OECD Economies. Research in Applied Economics, 6(3), 1-16. http://dx.doi.org/10.5296/rae.v6i3.5354

Bertola, G., \& Drazen, A. (1993). Trigger points and the budget cuts: Explaining the effects of fiscal austerity. American Economic Review, 83(1), 11-26.

Biswal, B., Dhawan, U., \& Lee, H. Y. (1999). Testing Wagner versus Keynes Using Disaggregated Public

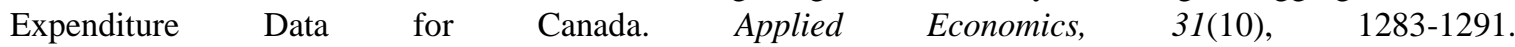
http://dx.doi.org/10.1080/000368499323490

Burney, N. A. (2002). Wagner's hypothesis: evidence from Kuwait using cointegration tests. Applied Economics, 34(1), 49-57. http://dx.doi.org/10.1080/00036840010027540

Chang, T. (2002). An Econometric Test of Wagner's Law for Six Countries based on Cointegration and Error-Correction Modelling Techniques. Applied Economics, 34(9), 1157-1169. http://dx.doi.org/10.1080/00036840110074132.

Chimobi, O. P. (2009). Government expenditure and national income: A causality test for Nigeria. European Journal of Economics and Political Studies, 2(2), 1-11.

Cotsomitis, J. A., Harnhirun, S., \& Kwan, A. C. C. (1996). Co-integration Analysis and the Long-Run Validity of Wagner's Hypothesis: Evidence from the People's Republic of China. Journal of Economic Development, $21(2), 1-10$.

Dogan, E., \& Tang, T. C. (2006). Government expenditure and national income: Causality tests for five South-East Asian countries. International Business and Economics Research Journal, 5(10), 49-58. http://dx.doi.org/10.19030/iber.v5i10.3516

Ebaidalla, E. M. (2013). Causality between Government Expenditure and National Income: Evidence from Sudan. Journal of Economic Cooperation and Development, 34(4), 61-76.

Enders, W., \& Granger, C. W. C. (1998). Unit-Root Tests and Asymmetric Adjustment with an Example Using the Term Structure of Interest Rates. Journal of Business and Economic Statistics, 16(3), 304-311. http://dx.doi.org/10.1080/07350015.1998.10524769

Enders, W., \& Siklos, P. L. (2001). Cointegration and Threshold Adjustment. Journal of Business and Economic Statistics, 19(2), 166-176. http://dx.doi.org/10.1198/073500101316970395

Frimpong, J. M., \& Oteng-Abayie, E. F. (2009). Does the Wagner's hypothesis matter in developing economies? Evidence from three West African monetary zone WAMZ countries. American Journal of Economics and Business Administration, 1(2), 141-147.

Gadinabokao, L., \& Daw, D. (2013). An empirical examination of the relationship between government spending and economic growth in South Africa from 1980 to 2011. Mediterranean Journal of Social Sciences, 4(3), 235-242. http://dx.doi.org/10.5901/mjss.2013.v4n3p235

Ghali, K. H. (1999). Government size and economic growth: Evidence from a multivariate cointegration analysis. Applied Economics, 31(8), 975-987. http://dx.doi.org/10.1080/000368499323698

Giavazzi, F., Jappelli, T., \& Pagano, M. (2000). Searching for non-linear effects of fiscal policy: Evidence from industrial and developing countries. European Economic Review, 44(7), 1259-1289. http://dx.doi.org/10.1016/S0014-2921(00)00038-6

Hassan, M., Murat, C., \& Demet, C. (2008). Wagner's hypothesis: New evidence from Turkey using the bounds 
$\begin{array}{llllll}\text { testing approach. Journal of } & \text { Economic }\end{array}$ http://dx.doi.org/10.1108/01443580810844442

Huang, C. J. (2006). Government Expenditures In China And Taiwan: Do They Follow Wagner's Law? Journal of Economic Development, 31(2), 139-148.

Islam, A. M. (2001). Wagner's law revisited: Cointegration and exogeneity tests for the USA. Applied Economics Letters, 8(8), 509-515. https://doi.org/10.1080/13504850010018743

Johansen, S., \& Juselius, K. (1990). Maximum likelihood estimation and inference on cointegration with applications to the demand for money. Oxford Bulletin of Economics and Statistics, 52(2), 169-210. http://dx.doi.org/10.1111/j.1468-0084.1990.mp52002003.x

Kamasa, K., \& Ofori-Abebrese, G. (2015). Wagner or Keynes for Ghana? Government expenditure and economic growth dynamics: A VAR Approach. Journal of Reviews on Global Economics, 4, 177-183. http://dx.doi.org/10.6000/1929-7092.2015.04.18

Kapetanios, G., Shin, Y., \& Snell, A. (2003). Testing for a unit root in the nonlinear STAR framework. Journal of Econometrics, 112(2), 359-379. http://dx.doi.org/10.1016/S0304-4076(02)00202-6

Keho, Y. (2015). Revisiting Wagner's Law for selected African Countries: A Frequency Domain Causality Analysis. Journal of Statistical and Econometric Methods, 4(4), 55-69.

Keho, Y. (2016). Testing Wagner's Law in the presence of Structural Changes: New Evidence from Six African Countries. International Journal of Economics and Financial Issues, 6(1), 1-6.

Keynes, J. M. (1936). The General Theory of Interest, Employment and Money. London: McMillan.

Kwiatkowski, D., Phillips, P. C. B., Schmidt, P., \& Shin, Y. (1992). Testing the null hypothesis of stationarity against the alternative of a unit root: How sure are we that economic time series have a unit root? Journal of Econometrics, 54(1-3), 159-178. http://dx.doi.org/10.1016/0304-4076(92)90104-Y

Magazzino, C. (2012). Wagner versus Keynes: Public spending and national income in Italy. Journal of Policy Modeling, 34(6), 890-905. http://dx.doi.org/10.1016/j.jpolmod.2012.05.012

Magazzino, C., Giolli, L., \& Mele, M. (2015). Wagner's Law and Peacock and Wiseman's Displacement Effect in European Union Countries: A Panel Data Study. International Journal of Economics and Financial Issues, 5(3), 812-819.

Menyah, K., \& Wolde-Rufael, Y. (2012). Wagner's law revisited: A note from South Africa. South African Journal of Economics, 80(2), 200-208. http://dx.doi.org/10.1111/j.1813-6982.2011.01275.x

Muse, B., Olorunleke, K., \& Alimi, R. S. (2013). The effect of federal government size on economic growth in Nigeria, 1961-2011. Developing Country Studies, 3(7), 68-76.

Mutuku, C. M., \& Kimani, D. K. (2012). Investigating Wagner's law-cointegration and causality tests for Kenya. Current Research Journal of Economic Theory, 4(2), 43-52.

Narayan, P. K., Nielsen, I., \& Smyth, R. (2008). Panel data, Cointegration, Causality and Wagner's law: Empirical Evidence from Chinese Provinces. China Economic Review, 19(2), 297-307. http://dx.doi.org/10.1016/j.chieco.2006.11.004

Narayan, P., Prasad, A., \& Singh, B. (2008). A test of the Wagner's hypothesis for the Fiji islands. Journal of Applied Economics, 40(21), 2793-2801. http://dx.doi.org/10.1080/00036840600972472

Narayan, S., Rath, N. B., \& Narayan, P. K. (2012). Evidence of Wagner's law from Indian states. Economic Modelling, 29(5), 1548-1557. http://dx.doi.org/10.1016/j.econmod.2012.05.004

Odhiambo, N. M. (2015). Government Expenditure and Economic Growth in South Africa: An Empirical Investigation. Atlantic Economic Journal, 43(3), 393-406. http://dx.doi.org/10.1007/s11293-015-9466-2

Ogbonna, B. C. (2012). Does the Wagner's law hold for Nigeria? 1950-2008. Journal of Research in National Development, 10(2), 290-299.

Ogbonna, B. C. (2015). Testing for Wagner's Law on Greek Economy. International Journal of Development and Economic Sustainability, 3(5), 26-35.

Olomola, P. (2004). Cointegration Analysis-Causality Testing and Wagner's Law: The Case of Nigeria, 1970-2001. Journal of Social and Economic Development, 6(1), 76-90.

Omoke, P. (2009). Government Expenditure and National Income: A Causality Test for Nigeria. European Journal 
of Economic and Political Studies, 2(2), 1-11.

Paul, F., \& Furahisha, G. (2017). Government Expenditure and Economic Growth Nexus: Wagner's law or Keynesian Hypothesis for Tanzania? African Journal of Economic Review, 5(1), 32-47.

Perotti, R. (2002). Fiscal policy in good times and bad. Quarterly Journal of Economics, 114(4), 1399-1436. http://dx.doi.org/10.1162/003355399556304

Pesaran, H., Shin, Y., \& Smith, R. J. (2001). Bounds Testing Approaches to the Analysis of Level Relationships. Journal of Applied Econometrics, 16(3), 289-326. http://dx.doi.org/10.1002/jae.616

Phillips, P. C. B., \& Perron, P. (1988). Testing for a Unit Root in a Time Series Regression. Biometrika, 75(2), 335-346. https://doi.org/10.1093/biomet/75.2.335

Pippenger, M. K., \& Goering, G. E. (1993). A Note on the Empirical Power of Unit Root Tests Under Threshold

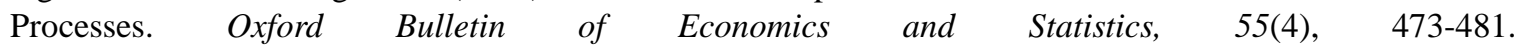
http://dx.doi.org/10.1111/j.1468-0084.1993.mp55004007.x

Ram, R. (1987). Wagner's hypothesis in time-series and cross-section perspectives: Evidence from "real" data for 115 countries. Review of Economics and Statistics, 69(2), 194-204. http://dx.doi.org/10.2307/1927226

Richter, C., \& Paparas, D. (2013). The validity of Wagner's Law in Greece during the Last Two Centuries. Applied Economics Quarterly, 59(4), 331-360. http://dx.doi.org/10.3790/aeq.59.4.331

Salih, M. A. R. (2012). The Relationship between Economic Growth and Government Expenditure: Evidence from Sudan. International Business Research, 5(8), 40-46. http://dx.doi.org/10.5539/ibr.v5n8p40.

Samadi, A. H., \& Abolhasan, B. K. (2013). Testing Wagner's Law in Selected OIC member States Evidence from Panel Cointegration Tests. Quarterly Journal of Economic Issues and Policies, 20(64), 115-130.

Sevitenyi, N. (2012). Government expenditure and economic growth in Nigeria: An empirical investigation (1961-2009). The Journal of Economic Analysis, 3(1), 38-51.

Singh, B., \& Sahni, B. S. (1984). Causality between Public Expenditure and National Income.The Review of Economics and Statistics, 66(4), 630-644. http://dx.doi.org/10.2307/1935987

Sinha, D. (1998). Government expenditure and economic growth in Malaysia. Journal of Economic Development, 23(2), 71-80.

Srinivasan, P. (2013). Causality between public expenditure and economic growth: The Indian Case. International Journal of Economics and Management, 7(2), 335-347.

Thabane, K., \& Lebina, S. (2016). Economic growth and government spending nexus: Empirical evidence from Lesotho. African Journal of Economic Review, 4(1), 86-100.

Thornton, J. (1999). Cointegration, causality, and Wagner's Law in $19^{\text {th }}$ century Europe. Applied Economics Letters, 6(7), 413-416. http://dx.doi.org/10.1080/135048599352916

Udo, A. B., Effiong, C. E., \& Ogar, O. O. (2016). Economic growth of West African Countries and the Validity of Wagner's Law: A Panel Analysis. Asian Journal of Economics and Empirical Research, 3(1), 71-83. http://dx.doi.org/10.20448/journal.501/2016.3.1/501.1.71.83

Wagner, A. (1958). Three Extracts on Public Finance. In R. A. Musgrave, \& A. T. Peacock (Eds.), Classics in the Theory of Public Finance (pp. 1-15). London: Macmillan.

\section{Copyrights}

Copyright for this article is retained by the author(s), with first publication rights granted to the journal.

This is an open-access article distributed under the terms and conditions of the Creative Commons Attribution license (http://creativecommons.org/licenses/by/4.0/). 